TEME, г. XLIII, бр. 4, октобар - децембар 2019, стр. 1141-1156

Прегледни рад

Примљено: 29. 10. 2019.

https://doi.org/10.22190/TEME191029068B

Ревидирана верзија: 5. 11. 2019.

UDK 355.4:327(73)

Одобрено за штампу: 1. 12. 2019.

$355.01: 327(73)$

\title{
MILITARY POWER IN US FOREIGN POLICY - TRADITION AND CHALLENGES
}

\author{
Veljko Blagojević \\ University of Defence, Strategic Research Institute, Belgrade, Serbia \\ veljko_blagojevic_55@hotmail.com
}

\begin{abstract}
When considering the military power of the United States, it is necessary to distinguish military force and military power. Military force represents an organization that is equipped and trained to use force. America is clearly the largest military power in the world, and that is a fact. However, the term military power is significantly wider than that of the military force. It also includes elements related to the threat of using force and many other activities related to the involvement of military force in contemporary international relations, including international defense cooperation, military-technical cooperation, the purchase and sale of weapons and military equipment, and more. The paper focuses on this exact segment of military power, understood as a willingness to engage the US military force outside their national territory. The aim of the paper is to describe the evolution of the United States' strategic thought regarding military power as a foreign policy instrument by analyzing the key processes in specific historical conditions from their independence to modern times. The results of this analysis will represent valuable indicators for a future role of military power in the US foreign policy in terms of potential conflicts for the preservation of global hegemony.
\end{abstract}

Key words: $\quad$ United States, Military Power, Strategy, International Relations, Global Hegemony.

\section{ВОЈНА МОЋ У СПОЉНОЈ ПОЛИТИЦИ САД - ТРАДИЦИЈА И ИЗАЗОВИ}

\footnotetext{
Апстракт

Када се разматра војна моћ Сједињених Држава, нужно је направити дистинкцију између војне силе и војне моћи. Војна сила представља организацију која је опремљена и оспособљена да примењује силу. Америка недвосмислено представља највећу војну силу на свету, што и није истраживачки изазов. Међутим, појам војне моћи је значајно шири од војне силе, јер укључује и елементе који су везани за претњу употребом силе и многе друге елементе пројектовања војне силе у савременим међународним односима, међу којима су међународна сарадња у области одбране, војно-техничка сарадња, продаја наоружања и војне опреме и друго. Управо је сегмент војне моћи, схваћен као спремност да се ангажује војна сила САД ван на-
} 
ционалне територије, предмет истраживања овог рада. Дакле, кључно питање овог рада није да ли Америка може да се војно ангажује, већ да ли има политичку вољу за то. Циљ рада је описати еволуцију америчке стратешке мисли о војној моћи као инструменту спољне политике, и то анализом кључних процеса у конкретним историјским условима од независности до савременог доба. Резултати ове анализе представљаће показатеље за будућу улогу војне моћи у спољној политици Сједињених Држава у контексту потенцијалног сукоба за очување глобалне хегемоније.

Кључне речи: Сједињене Државе, војна моћ, стратегија, међународни односи, глобална хегемонија.

\section{INTRODUCTORY CONSIDERATIONS ON MILITARY POWER}

Power is a key concept in international relations studies, while military power has represented, represents and will represent an essential factor in determining the straight gradient of each of the subjects pertaining to international politics. Military power is usually determined by the quantity and quality of weapons as well as military equipment, the ability to effectively command units, and by their combat morale. Having military superiority enables countries to both plan and implement their foreign policy more ambitiously, and because of their ultimate support for other elements of power, they can influence other actors in international politics. The logic behind military power is quite simple: military force symbolizes intimidation and destruction. Overwhelming military power provides a greater likelihood for potential opponents to persuade, dissuade or be forced to postpone action that would harm national interests. Military power can reach full effectiveness and efficiency only when it is undoubtedly sufficient (Freeman, 2002, p.18).

Military power essentially has three applications in the strategic context: deterrence, coercion and defense. It has the potential of enforcement against a state or non-state actor to: prevent something or prevent the realization of certain plans (deterrence), change the behavior of potential adversaries (coercion), and protect state property from harmful actions of other players in the international system (defense) (Art, 2003, p. 3). Due to its destructive nature and potential to threaten the existence of others, military power is most effective in controlling and forcing other subjects, while supporting other foreign policy tools to achieve the desired goals. The possession of military power is a reliable support for self-help in case of aggression, but it can also serve as a support for other instruments of power. After all, the balance of power in the international order is a balance of all the options and instruments available to the states to achieve their goals (Slović, 2009, p. 178). Military power is one of the traditional components of the power calculus, which "measures" the state's ability to influence world politics.

Training, military morale, and leadership are important qualitative factors of the military force. Small and professional forces that undergo 
intensive training are usually far more capable than large numbers of untrained soldiers. Morale is also crucial to the overall readiness of the military. According to Machiavelli, the introduction of the idea of patriotism gave the armed forces a deeper meaning, a notion of fulfillment among soldiers that bolstered their will to fight (Paret, 1986, pp. 25-27).

The American and French revolutions have left a significant mark on human society in general, and on military organization, which is primarily related to the introduction of mass recruitment of the population. Before the revolutions, wars represented conflicts between the rulers. Those forms of the state, reflected through the hierarchy of classes, were also visible in the military structure. The armed forces were divided into classes: officers whose motives were honor and glory, while soldiers were usually perceived as incapable of any higher feelings other than lust for combat. Lack of discipline and training made huge battles almost unimaginable and very risky, which resulted in limited wars (Paret, 1986, pp. 91-95).

Despite the relative military stagnation in the pre-revolutionary period, Europe has witnessed intense foreign policy engagement by France in order to reduce the power of the Habsburgs. Namely, with the arrival of Cardinal Richelieu to power, political disintegration of Central Europe became the most important strategic objective for French foreign policy. In other words, the Cardinal saw the threat in the unification of Central Europe and how this could potentially compromise future French political interests. The Cardinal's reasoning suggested two key concepts. The great powers were aware, even then, of the concepts of the balance of power and how disruption of this balance could endanger their survival. Furthermore, Richelieu laid the foundations for the idea of a grand strategy that, in the case of France, should halt the unification of Central Europe, which lasted for more than two centuries until Bismarck's declaration of the German Empire.

Richelieu basically introduced the concept of "grand strategies". It can be described as a combination of political, economic and military power of the state establishing a way for the involvement at the international level. Grand strategies should articulate the priorities of national politics on the international level in accordance with the current capabilities of the state, where one of the most important factors is military power, as Colin Gray clearly explains "the direction and use of any or all of the potential of the security system, including its military instrument, for policy needs that are decided by political leadership" (Hoffman, 2014, p. 474). Nevertheless, the grand strategy does not strictly imply a military strategy or a foreign policy strategy, but rather represents a holistic approach to state power in the perspective of achieving the goals. Grand strategies should be able to answer two important questions, which is to define key national goals and how to achieve them (Murdock \& Kallmyer, 2011, p. 542).

Although the revolutions of the late XVIII century introduced various innovations in military technology and strategy, their significance 
was in the political nature of the American, as well as the French Revolution. The union of the government with the people enabled the people to participate in state affairs, and a certain degree of control over the work of the ruling structure, which was not possible before. This sense of participation in the government created a new social reality which in turn resulted in the creation of a sense of patriotism and implied that the population should fight for their state with devotion. However, governments were the ultimate beneficiaries of the revolution. The ruling establishment easily, and relatively quickly, transformed the right to defense into a normative obligation to defend the homeland. Political elites acquired sovereign rights to militarily organize all available human and material resources. Thus, relatively limited dynastic wars evoked conflicts of entire societies. Wars became an instrument for achieving political goals, which is often discussed by Klauzevic (Blagojevic \& Pejic, 2019, pp. 15/16).

\section{U.S. MILITARY POWER UNTIL THE GREAT WAR}

American colonies made a significant contribution to the Seven Years' War (1756-1763) and were expected to be rewarded for such behavior. Instead, the British Parliament introduced direct taxes and the colonies responded with civil disobedience. Under the famous slogan, "No Taxation without Representation", they continued to fight for their rights. The inflexibility of London led to the rebellion of colonies in North America in 1775. At the beginning of the war, the rebel colonies had a large number of members of militia and military forces who participated in the previous war. Hoping to diminish Britain's power, France, Spain and the Netherlands joined the war. With insufficient resources to wage effective "positional" warfare, General Washington managed to force Britain to sign the peace agreement in Paris in 1783, by implementing a strategy of partisan warfare.

The British Navy represented a strategic advantage over the American rebels. Their victory wouldn't have been expected if the Allied naval support had not arrived in time. Therefore, immediately after independence, US began building the Navy. Unlike the development of naval forces, to which the US paid constant attention, the active component of the Army was of minor status as they relied on state militia as the mainstay of the revolution. From independence to 1812 , the US paid no attention to strategic thinking; drafting only a few military handbooks; they had no adequate domestic literature of strategic and doctrinal provinces (Weigley, 1973, p. 18-55).

The US adopted the Monroe Doctrine in 1823, stating that America would have the obligation to intervene if European forces militarily engaged in North or South America. At the same time, the US pledged not to interfere in the internal affairs of the existing colonies. At that time, it was unusual for a non-European country to make any kind of request to European powers, 
and even less to demand the limitation of European colonial ambitions. The adoption of the Monroe Doctrine also pointed out the emergence of "exceptionalism" and the Manifest Destiny in American culture and politics, which will become its important determinants, especially in foreign policy. The Monroe Doctrine gave pretext to a lot of US military interventions in Latin and Central America over the next few decades (Johnson, 1991, pp. 5055). Reliable armed forces, especially the Navy, were necessary for military interventions, which the leaders of the United States were aware of, and therefore established a firm commitment to reach that goal.

The US Army remained relatively small in the age of the Indian wars. A key figure in American development was General Scott Winfield, who served as Chief of the Army General Staff for two decades. He insisted on the discipline and skills of the soldiers, and his strategic commitment was to create a small and professional army, unlike the massive armies that Napoleon had introduced in Europe. The war with Mexico began and General Winfield believed that the key to victory was not in the destruction of the opponent, but in the political pressure on the weaknesses of the Mexicans. Like the European empires, the Mexicans' weakness was the sensitivity to the security of the capital. This is why a campaign to seize Mexico City was launched, supported by solid political preparation. The result was victory in the Mexican War (1846-1848) and the US almost doubling their national territory (Weigley, 1973, p. 59-76).

The long-lasting problem that divided the American society was the issue of slavery. Disputes culminated during the handover of presidency in 1861, when seven southern states declared secession from the United States and formed the Confederation. President Lincoln ordered an attack on one of the fortresses in South Carolina and called for conscription, which resulted in four southern countries joining the Confederation. The North won in the civil war, which caused heavy casualties and destruction. This was the first major industrial war, which required the engagement of the entire society, not only in the combat, but also in the production of weapons and military equipment (Johnson, 1991, pp. 55-56).

The American naval power was proved in the brief SpanishAmerican War of 1898, which ended the Spanish colonial presence in the Western Hemisphere. The US victory forced Spain to give up possession in Cuba as well as Guam, Puerto Rico and the Philippines, giving the US primacy in the Caribbean region and a position to protect their interests in Asia (The Spanish-American War, 1898).

At the beginning of the Great War, the US pursued an isolationist policy. After the re-election in November 1916, President Woodrow Wilson launched an unsuccessful diplomatic initiative to stop the war in Europe. In WWI, the US involved itself in 1917 on the side of the UK and allied powers, which was previously provided by large US war loans. That same year, the Bolshevik Revolution started and Russia signed a separate 
peace agreement with the Central Powers. In a short period of time, the US mobilized about 2 million troops for the European front, while their industry demonstrated great potential to support the war effort. The US managed to organize the transport of troops and military equipment to Europe. The Central Powers did not expect that. The biggest winners of WWI were the US, which used its economy to meet the Allies' war needs and take over the traditional European markets around the world. After the war, the financial center of the world moved from London and Paris to New York. The end of the war brings Wilson's program of the famous 14 Points, which established the League of Nations, as well as the so called sanitary corridor or the strategic buffer zone between Europe and USSR.

However, the US did not join the League of Nations, but returned to isolationism. At the same time, the personnel of the professional army were reduced, as well as their defense budget. The exception was, partly, the retained powerful Navy. It can be said that the decision to do so was in accordance with the liberal views that traditionally require a small and functional state apparatus and the armed forces, and the US could have been categorized as such, because there were no significant threats to their national security.

\section{U.S. MILITARY POWER FROM ROOSEVELT TO REGAN}

Similar to WWI, the US pursued an isolationist foreign policy and sought to avoid engaging in WWII for as long as possible. In military terms, they were completely unprepared for the war effort, except for the Navy and partly the Air Force.

The US focused its military engagements on the Asian Pacific while suppressing the Axis forces in the Mediterranean. Japan's military expansion and conquest in China, Indochina, Thailand and the Philippines sought to establish a "new order" without Western powers in East Asia. Since the attack on Pearl Harbor, $7^{\text {th }}$ December 1941, the US and UK forces suffered heavy losses in manpower, armaments and space. The Battle of Midway, in June 1942, was a strategic turning point, as losses in vessels were equal, but the US was able to renew war equipment and manpower unlike Japan. With the allies' gradual takeover of the initiative, and especially after the Battle of Leita, the Japanese Navy was no longer a real threat. The capabilities of the Japanese naval transport were hampered by the operation of US submarines. During the war, the Japanese Air Force constantly lost its potential, both in manpower and armaments. From September 24, 1944 until August 14, 1945, the US Air Force bombed Japanese territory and military installations in China (Kovač \& Forca, 2000, pp. 25-26).

President Harry Truman was advised by the Special Commission to use a nuclear bomb against Japan. That same month, the Potsdam Declaration was adopted, and the Allies sought the surrender of Japan, under the threat of facing large-scale destruction. Since Japan responded negatively, 
President Truman ordered the use of the first atomic bomb on Hiroshima on $6^{\text {th }}$ August 1945. Three days later, the bomb was thrown on Nagasaki, and the USSR entered the war against Japan. All of this resulted in the capitulation signed by the Japanese Emperor on September 2, 1945 (Kovač \& Forca, 2000, pp. 25-26). Thus, in addition to rescuing its own losses in the war against Japan, the US opened the Pandora's Box of international security, which was reflected in the challenge to possess nuclear weapons and the readiness to use it. The possession of nuclear weapons has become imperative for the second superpower of that time, the USSR, and later for other major powers as well. These weapons still pose a major threat today not only to international security but also to the survival of human civilization.

With Normandy landings in June 1944, the US and its allies came to Europe, which was occupied by the Nazis. From then on, the US military has been present in Europe to this very day. The continuing presence of US military forces in Europe serves as a great reminder that military power is a significant foreign policy instrument not only for war, but also for the preservation of peace. The US has maintained respectable peacetime armed forces and a defense budget that is still the largest in the world. All postwar strategy documents of the US clearly define a commitment to keep their military power unchallenged worldwide. At the same time, the US secured global economic-financial dominance through Breton Woods Institutions. In this way, Washington has provided two of the most significant foreign policy instruments, military and economic, that have been shaped and implemented by politics and diplomacy.

After WWII, an ideological confrontation ensued between former allies from the West and the East. The NATO (1949) and the Warsaw Pact (1955) were formed, and the world was divided according to different ideological orientations. The Cold War era arose, which was replete with various military interventions by both super powers, but mostly within the boundaries of the defined sphere of interest, as was the case with the Monroe Doctrine in Latin America. The Soviet's interventions in Hungary, Czechoslovakia and Afghanistan, on the other hand, indicated that military power was a first-class foreign policy instrument. The Cold War was filled with various crisis situations, which threatened not only peace but also the survival of the human civilization, as the nuclear superpowers had sufficient potential to destroy the world (Gedis, 2003; Blagojevic \& Pejic, 2019, pp. 115-232). Global strategies of containment, deterrence, USSRdirected "anaconda" and the constant arms race were the major determinations of the US foreign policy during the Cold War that include a large scale of military cooperation and arms sales to a friendly state.

The failure of the US Armed Forces in Vietnam shows that lack of morale and increased stress among soldiers, as well as inadequate military budgets and political demonstrations at home, resulted in overall losing support of the public for continuing the war campaign in Vietnam. In fact, one of the main reasons for the US withdrawal from Vietnam was the 
lack of political support for the war effort, which was very badly reflected across all levels of military structures, resulting in the demoralization of soldiers directly involved in the war (Paret, 1986, pp. 25-27).

The defeat in Vietnam had a negative impact not only on the morale and reputation of the US Armed Forces, but also on its overall foreign policy. American presidents did not show the will to engage military power outside the national territory until the end of the Cold War, except for "smaller" military interventions such as the one in Granada or the bombing of Libya. The US overcame the "Vietnam Syndrome" only after the 1991 Iraqi War.

After their defeat in Indochina, America withdraws from Angola, and Soviet and Cuban forces move from Angola to Ethiopia, the Soviets enter Afghanistan, and Iranian fundamentalists overthrow Shah Pahlavi and capture US citizens at the Embassy in Tehran. As Kissinger correctly pointed out, "it has never happened in history that a world power collapses so quickly and thoroughly even though it was not defeated in the war" (Kissinger, 1999, p. 679). The arrival of President Ronald Reagan on power in 1981 is a milestone in foreign policy that is based on the desire to "reaffirm the traditional code of belief of US exceptionalism" (Kissinger, 1999, p. 678).

President Regan adopted the Strategy of Low-Intensity Conflicts, which sought to systemically address the shortcomings that led to the defeat in Vietnam. These are primarily political shortcomings in the strategic approach to the war in Indochina. The UK's experience in fighting postWorld War II colonial insurgents was taken as a starting point for a new strategy, and the engagement spectrum is given in the appendix that follows.

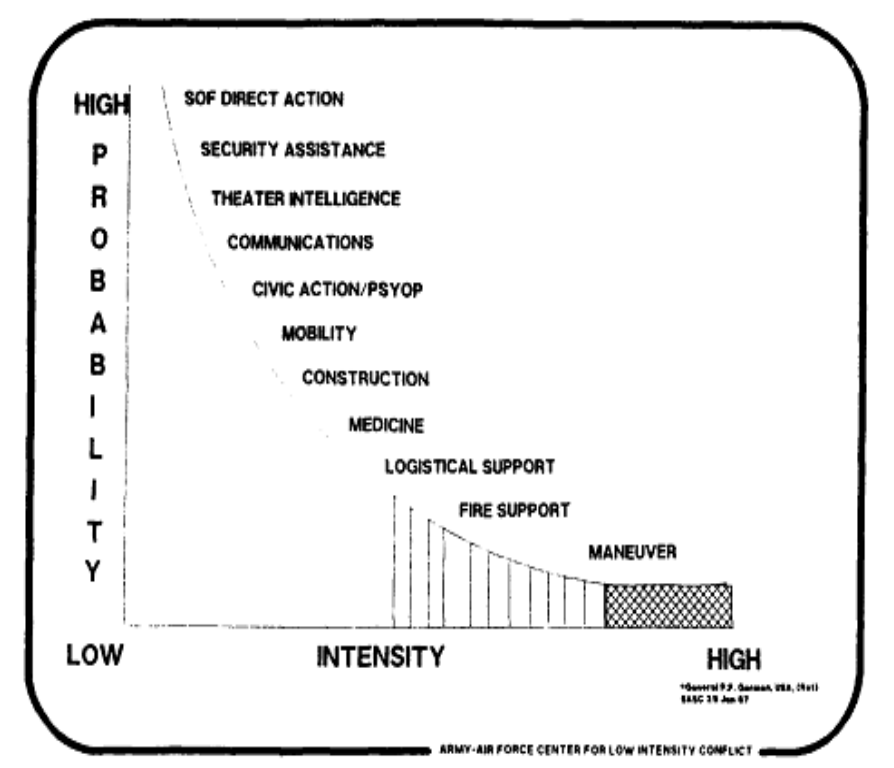

Graph 1. Intensity of Engagement in Low-Intensity Conflict (Low Intensity Conflict, 1989, p. 30) 
The strategy was initially intended to counter the revolutionary communist movements, and its implementation was accompanied by resistance from the US officer corps as they felt that their traditional warlike spirit implied the destruction of the enemy rather than political outburst with the enemy.

President Regan succeeded in uniting the nation and pursuing the foreign policy that led to the collapse of the USSR. He abandoned the détente favored by his predecessor, Jimmy Carter, and imposed a "new arms race" on the Soviets, who could not stand the tempo, especially after the withdrawal from Afghanistan. President Gorbachev announced the political program known as the "perestroika", which was a prelude to the breakup of the Warsaw Pact and the USSR, as well as the end of the Cold War era.

\section{AMERICAN MILITARY POWER FROM H. W. BUSH TO OBAMA}

In the last decade of the XX century, the US had a prominent position in international politics, as the only remaining superpower, and the ideological winner in the Cold War with the strongest world economy. That victory also entailed a tremendous responsibility, as the undoubted global leader who had an almost unique position in modern history to crucially influence the course of events in international politics. The opening of the market of the former Eastern Bloc accelerated the process of globalization and entrenched liberal thought as a significant theoretical basis in international relations.

Nevertheless, the US decided that NATO was still a valuable instrument of their foreign and security policy and needed to survive, despite the fact that the Warsaw Pact was terminated. Together with the Allies, they changed the priorities of NATO in line with the changed circumstances in international relations. The main objective was to fill the "security vacuum" in Europe created by the collapse of the Warsaw Pact, which is defined by the "open door" policy for European states. The US is the world largest arms exporter and uses that to pursue its foreign policy goals. Ultimately, the policy resulted in the expansion of the Alliance to the East, which was increasingly opposed by Russia.

The rapid development of information and communication technologies introduced a real-time dimension into the combat zone. Leading developed nations, most notably the US, have been able to effectively deploy new technologies into their armed forces, triggering the so-called Revolution in Military Affairs (RMA). The most important aspect of RMA is the great divide created by this revolution between those who can follow the fast pace of new technologies and those who do not have the capabilities. It soon became apparent that the "unipolar moment" in international relations was caused not only by the dissolution of the Warsaw Pact and the USSR, but also by the enormous military-technological superiority of America. The next 
generation of the US Armed Forces was able to reach almost every target anywhere on the planet, while potential enemies were almost incapable of setting up effective defense or retaliation measures. Those who spearheaded the revolution in military affairs were in a position to easily make and execute foreign policy decisions, using the threat of force or engaging with military force without the fear of retaliation from other subjects of international politics (Blagojevic \& Pejic, 2019, pp. 115-232).

The technological innovations implemented at the tactical level will affect the overall strategy and thus affect the overall potential at the foreign policy level. New technology has dispelled the "fog of war" for actors in the arm conflict. War is a fierce competition between opponents, and that is why the armed forces are constantly modernizing themselves to outsmart a potential or actual enemy (Gray, 1990, pp. 110-197).

Although modern weapons and military equipment allow soldiers to beat their technologically inferior enemy, it should not be treated as the primary means of victory in modern-day military operations. In many cases it was evident that morale, combat readiness, tactical and strategic approach, as well as geography and other traditional-structural factors of war, proved their importance in post-Cold War wars. Despite the smaller number of modern armed forces due to the revolution in military affairs, the actual military budgets of many states, especially the US, Russia and China, were higher than before. Many states have been more prone to military spending in order to boost their military technology, even though the imminent threat of war "against the great enemy," such as the USSR, was no longer realistic (Blagojevic \& Pejic, 2019, pp. 115-232).

NATO engaged militarily, for the first time in its history, outside the territory of the member states against the Serbian forces in Bosnia and Herzegovina in 1995, and several years later in the military operation "Allied Forces" against the FRY. This introduced the concept of "humanitarian intervention" into the practice of international relations, as well as in the concept of international law, even though defending the morality of such novel phenomenon was not only questionable but reasonably difficult. Twenty years after these events, the alleged moral motives of the military intervention are more than clear to all (Blagojević, 2019, pp. 365-384). Despite the revolution in military affairs, which had a major impact on the characteristics of modern warfare and substantially reduced the number of states capable of "keeping up with technological advances", the US has not abandoned the implementation of the low-intensity conflict strategy. The US involvement in the conflicts in the Balkans in the last decade of the XX century speaks convincingly in favor of that fact.

The 9/11 terrorist attacks have been a pivotal event since the beginning of the new millennium, which has changed not only America's foreign and security policies, but international relations as a whole. The strategic response was in the planning for a year, confirming that the US 
was unprepared for terrorist threats of that magnitude on its own territory. The National Security Strategy of the US issued on September 2002 promotes the global fight against Islamic terrorism by all available means of power, especially military power, but also by the "fight for hearts and minds" worldwide.

This strategy has promoted another concept, which is problematic in many ways. These are the so-called preemptive strikes against terrorist threats anywhere in the world - preemptive measures with the purpose of destroying potential threats before they become a real danger. This concept has many elements of excellence and manifest destiny, a source of morale and philosophy the US has drawn inspiration from often throughout history. Namely, they give themselves the opportunity to act in a way that is not acceptable to others, or at least most of the subjects of international relations. America gave itself the right to act against terrorists, no matter on whose territory they were located, thus undermining the concept of state sovereignty. The unilateralism of the US in its fight against Islamic terrorism formed the basis for President G. W. Bush's strategic approach to counterterrorism. During the presidency of Barack Obama, the fight against terrorism became an increasingly multilateral approach. Yet, more and more often, the foreign policy of the US could be seen in favor of military means in countering terrorism, while the "fight for hearts and minds" was generally put into the background.

The US military engagement in Afghanistan gained the support of most subjects of international politics, which was not the case with the war in Iraq. America is still militarily present in these countries, but the goals of their engagement have not been met. The situation was further complicated by the appearance of the so-called Islamic state, first in the Iraqi territory and then neighboring Syria. Obviously, the military means predominantly used by the US are inadequate to address the complex problems of religious extremism and backwardness. One gets the impression that America is on track to lose the "fight for hearts and minds" and that it simply has not resisted the challenge of "arranging the world in its own model".

\section{CONCLUDING CONSIDERATIONS ON THE ROLE OF MILITARY POWER IN MAINTAINING AMERICAN HEGEMONY}

For many years, scientists have debated the future of international relations and the fate of global leadership. The key questions pertain to who the challengers to American hegemony are, and what the structure of international relations will look like in the future. The question is focused on the "challenger" list, which most often refers to China, then Russia, India, Brazil, individually, or more likely united. There are a lot of assessments that China will most probably reach the US in economic power, and it is a fact that Beijing is rapidly developing military power in 
cooperation with Russia. However, there are also objective limitations to China's effective bid for the global leader, such as the lack of naval forces to project military power, influence in international organizations, and other more or less questionable deficiencies in the full spectrum of power.

On the other hand, there are also respectable arguments that point out that the US will have the capacity and potential that are unavailable to challengers for the foreseeable future.

"The unique position of US in the hierarchy of the world today is widely recognized and accepted. ... The modern world may not like American supremacy - it may not trust it, be reluctant to it, it may even occasionally oppose it, but in practice they cannot directly oppose it. To no avail, the Chinese and Russians flirted with a strategic partnership to promote global "multipolarity" - a term that can clearly be translated as counter-hegemony." (Bžežinski, 2005, p. 13)

In these words, the well-known theorist Zbigniew Brzezinski described the US position in the modern world and the alternatives in global leadership in 2003.

However, since then, many significant processes in international relations have taken place, which gradually, but continually seem to influence the image of America as a global hegemon. The world economic crisis, which started in the US, had negative impact on America's "soft power". The US forces have huge problems in stabilizing the security situation in Afghanistan and Iraq, which puts into question the adequacy of the US engagement in the fight against global terrorism. Islamic states in Iraq and Syria, whose ideology is based on extreme Islamism and antiAmericanism, have clearly shown a strong resistance to the Western system of values.

Russia's military engagement in Georgia and the crisis in Ukraine that ultimately resulted in the annexation of Crimea, clearly indicate that Moscow is ready to act in accordance to their strategic documents defining its immediate neighborhood a priority of engagement in stopping the process of NATO's expansion to the east. The "Arab Spring" showed all the complexity and unpredictability of Islamic societies. The latest in a series of "awakening nations" in Syria sparked a civil war, which definitely confirmed that Russia has the political will and potential for military engagement abroad.

During this period, the US has been restrained and to a larger extent left its allies within the Alliance to act, providing them with command and logistical support through NATO Command that implemented operations such as the one in Libya or the air strikes on targets in Syria.

It seems that the US has become aware that economic indicators do not give them optimism. Additionally, they are not convinced that military engagements in current crisis-hotspots are cost-efficient, especially with the 
risk of direct massive US military engagement. They want to avoid situations in which long-term military presence in unstable countries would be required, such as Afghanistan and Iraq, where they failed to resolve the security situation. Finally, this may well be the first hint that Washington has become aware of the fact that the conditions in international relations are not in favor of their military engagements, as well as the need to act in order to avoid the known danger of "imperial overstretch".

Of course, this does not mean that the US has exhausted its military power, but they have become more hesitant about direct military engagements. No doubts that Russia has contributed to this by engaging outside their national territory, as well as the increasingly respectable military power of China.

There is a real possibility that the US will fall into the so-called Thucydides trap and try to provoke China into conflict, such as those during the Cold War, in an effort to prevent China's further economic and military strengthening. These would not be direct armed conflict between the US and China or Russia due to the fact that these states are first-class nuclear powers and such conflicts are in all probability not considered by Washington. However, such an option is advocated by offensive realists who stress that "attack is the best defense" and the current situation in Thailand indicates the potential for such developments. Official Beijing seems to have a good understanding of the current US policy and "preventively" points out that they are for the peaceful settlement of all international disputes, except for those that are an internal issue of China.

In the last decade of XX century, the US abolished the centralized planning process for the armed forces, because there was no military rival that possessed the potential to counter American power in a large-scale war. It seems that the announcements of the re-introduction of these practices indicate that such time has passed and there are challengers. Maybe they have no capacity for confrontation to the entire spectrum of US military resources, but contenders might have sufficient capacity to lead "regional wars", if that is possible in the time of globalization. All this points to the fact that defensive realism, definitely is a much more reasonable option for the strategists in Washington, much like previously in American history, and considering their participation in the world wars. Moreover, it could be said that the US seeks to possess military power sufficient to crucially reverse the course of key events in international politics, thereby securing the position of a "balancing power" in the multipolar order that is announced while avoiding "exhausting" military potential by engaging in local wars. 


\section{REFERENCES}

Art, A. J., (2003), A Grand Strategy for America, Cornell University Press, Ithaca and London.

Bžežinski, Z., (2005), Američki izbor [The Choice], CID, Podgorica.

Blagojevic, V., Pejic, I., (2019), Military Power in International Politics, Past-PresentFuture, Lambert Academic Publishing.

Blagojević, V., (2019) „Psychological Operation in Low-Intensity Conflict - Case Study Kosovo and Metohija”, in Nebojša Vuković (ed.), David vs. Goliath: NATO War against Yugoslavia and its Implications, Institute of International Politics and Economics and Faculty of Security Studies, Belgrade.

Gedis, D., L., (2003), Hladni rat (We Now Know), Clio, Beograd.

Guč Dž. P. i Jovanović J. M. (1933), Diplomatska istorija moderne Evrope od Berlinskog kongresa do Versaljskog mira 1878-1919. [The Diplomatic History of Modern Europe from the Congress of Berlin to the Peace of Versailles 1878-1919], Geca Kon, Beograd.

Freeman Chas W. Jr. (2002), Arts of Power, United States Institute of Peace, Washington DC.

Gray S. C., (1990), War, Peace, and Victory: Strategy and Statecraft for the Next Century, Touchstone.

Hoffman F.G, (2014), Grand Strategy: The Fundamental Considerations, Foreign Policy Research Institute.

Johnson K. L., (1991), America as a World Power - Foreign Policy in a Constitutional Framework, McGraw-Hill, Washington DC.

Kisindžer, H., (1999), Diplomatija (Diplomacy), Verzal press, Beograd.

Kovač M., Božidar, F., (2000), Istorija srpske ratne veštine - period 1920-2000 [History of the Serbian Art of War 1920-2000], Vojnoizdavački zavod, Beogard.

Murdock C., Kallmyer, K., (2011), Applied Grand Strategy: Making Tough Choices in an Era of Limits and Constraint, Foreign Policy Research Institute.

Paret, P., (1986), Makers of Modern Strategy from Machiavelli to the Nuclear Age, Princeton University Press, New Jersey.

Slović, S., (2009), Aronova teorija medjunarodnih odnosa i aktuelno kosovsko pitanje [Aaron's Theory of International Relations and the Current Kosovo Issue], Institut za srpsku kulturu Priština, Leposavić.

Tomac. P., (1976), Prvi svetski rat 1914-1918. (WWI 1914-1918), Vojnoizdavački zavod, Beograd.

The Spanish-American War, 1898, https://history.state.gov/milestones/1866-1898/spanishamerican-war.

Waltz, K., (2001), Man the State and War, a Theoretical Analysis, Columbia University Press, New York.

Weigley, R. F., (1973), The American Way of War / A History of United States Military Strategy and Policy, Indiana University Press, Bloominigton.

"Low Intensity Conflict - Overview, Definitions, and Policy Concerns", Department of the Army and Department of the Air Force, Langley Air Force Base, Virginia, 1989. 


\title{
ВОЈНА МОЪ У СПОљНОЈ ПОЛИТИЦИ САД - ТРАДИЦИЈА И ИЗАЗОВИ
}

\author{
Вељко Благојевић \\ Универзитет одбране, Институт за стратегијска истраживања, Београд, Србија
}

\section{Резиме}

Ратничку традицију Сједињених Држава поштује читаво друштво. Дуго времена по осамостаљивању су САД имале малобројне оружане снаге и ослањале су се на народну војску, што је и била тековина Америчке револуције. И данас се америчке оружане снаге умногоме ослањају на резервни састав, односно националне гарде држава, иако у другачијим организацијским условима. Географска удаљеност од великих сила, слаби суседи и пространи океани створили су геостратешке и безбедносне услове за развој и територијална проширења „младе америчке републике”. Управо су океани условили развој ратне морнарице САД, која је дуго представљала једини приоритет оружаних снага, у складу са Махановом геополитичком теоријом, која фаворизује поморску моћ.

Усвајањем Монроове доктрине 1823. године, САД показују аспирације за учешће у светској политици и дефинишу Латинску Америку и Централну Америку као сопствену зону интереса. Европске силе тога доба заокупљене су колонијалним освајањима, а завршетак тог процеса је суштински довео до Првог светског рата. САД су све до 1917. године водиле изолационалистичку политику и давале кредите за ратне напоре европских држава. Убрзо након уласка у рат, Америка мобилише два милиона војника, њена полетна економија брзо се преоријентише на ратну производњу, а моћна морнарица организује масован транспорт трупа у Европу. То је за силе основине било стратегијско изненађење, које је допринело њиховом поразу. Председник Вилсон у програму од 14 тачака уређује послератну мапу Европе и утиче на целокупне међународне односе, али се након рата САД поново повлаче у изолационализам, драстично умањује бројност оружаних снага и буџет за одбрану. И Други светски рат су САД дочекале изолационистичком политиком, која је прекинута нападом на поморску базу у Перл Харбуру. Америка је брзо мобилисала војску и ратну индустрију. Главне снаге ангажује на азијском Пацифику, док су помоћне снаге ангажоване у Медитерану, а тек од 1944. године се значајније ангажује у Европи. САД су прве и једине употребиле нуклеарно оружје против Јапана, чиме су умањиле сопствене жртве у наставку рата, али и отвориле „Пандорину кутују” поседовања и претње употребом нуклеарног наоружања.

После Другог светског рата и поделе на окупационе територије, САД задржавају војно присуство у Европи и на овај начин напуштају традицију Вилсоновог идеализма и изолационализма. Сједињене Државе су ангажовањем сопствених војних капацитета у Европи, али и пружањем помоћи савезницима у оквиру НАТО, сузбијале експанзионистичке амбиције идеолошки супротстављеног блока, односно Варшавског уговора, који је располагао масовним конвенционалним копненим снагама, али и нуклеарним арсеналом СССР. Америка је, као „таласократска” сила, поред поморске моћи, користила и стратегију „анаконде”, засновану на геополитичком учењу Спајкмана, која је заснована на контроли приобалних територија превасходно евроазијског копна. У том контексту, треба посматрати и америчко ангажовање у Кореји, а касније и у Индокини. Управо је неуспешно војно ангажовање у сукобу у Вијетнаму довело до слабљења угледа САД, као суперсиле и појаве тзв. Вијетнамског синдрома, кога су се решили тек након Ирачког рата 1990/1991. године. Америка је, након неуспеха у Вијетнаму, усвојила стратегију сукоба ниског интензитета која је била усмерена против револуционарних покрета које је подстрекивао СССР. 


\section{6}

Успех Америке у Хладном рату треба несумњиво приписати војној моћи, која се најчешће умешно допуњавала економском и идеолошком супериорношћу.

Крај Хладног рата је САД поставио на лидерску позицију у међународним односима, као једине суперсиле и најмоћније економије у свету. САД су иницирале промене у приоритетима НАТО, који је добио задатак да попуни „безбедносни вакуум” настао у Европи након укидања Варшавског уговора. Алијанса је по први пут у историји дејствовала ван граница држава чланица у ратовима на Балкану у последњој деценији XX века. САД су на терористичке нападе на својој територији 2001. године одговориле доминантно војним средствима, која су резултирала масовним војним ангажовањем у Авганистану и Ираку. Иако су успешно реализоване операције заузимања територије, америчке снаге и данас имају проблеме у стабилизацији безбедносних прилика у наведеним државама и не назире се могућност реалних излазних стратегија из наведених сукоба. Униполарност је довела у искушење САД да доминантну војну моћ користе и према доктринама које су контроверзне по многим питањима. Реч је о „хуманитарним интервенцијама”, према којој је реализовано ангажовање НАТО на Балкану и „предухитрујућим ударима”, који су у доброј мери усложниле безбедносну ситуацију у Авганистану, Ираку и на Блиском истоку. Ангажовање према наведеним доктринама увећало је ангажовање оружаних снага, без сразмерне користи на плану стабилизације међународне безбедности и умањења терористичких претњи. Напротив, појава такозване Исламске државе на територији Ирака и Сирије указује на супротне ефекте, јер ангажовање војне моћи САД није адекватно праћено другим спољнополитичким средствима.

Појава потенцијалних изазивача америчке хегемоније на глобалном плану који јачају војне потенцијале - покренула је процес преиспитивања приступа и употребе војне моћи. Томе су допринели и опасност од „империјалног пренапрезања”, недостатак излазних стратегија из актуелних сукоба и други фактори. Може се рећи да САД настоје да избегну директно војно ангажовање у локалним сукобима, али је сасвим извесно да ће одржавати и унапређивати војне капацитете који ће бити способни да суштински утичу на кључне догађаје у међународној политици. 